Onder redactie van:

Prof. mr. dr. B.M.E.M. Schols

Prof. mr. dr. W. Burgerhart

Prof. mr. dr. F.W.J.M. Schols

Mr. F.M.H. Hoens

Mr. G.A. Tuinstra

Mr. J.Th.M. Diks

Mr. M.J.P. Schipper

Mr. dr. N.V.C.E. Bauduin

Mr. E.C.E. Schnackers

Mr. dr. J.W.A. Rheinfeld

\section{Advotip}

Erfrecht voor de advocaat

\title{
Een clash van hoven op overgangsrechtelijk bewindsterrein
}

Het ene hof is het andere niet, zo blijkt maar weer uit Hof Arnhem-Leeuwarden 7 juli 2016, ECLI:NL:GHARL:2016:5612 en Hof Den Bosch 21 juni 2018, ECLI:NL:GHSHE:2018:2687.

In deze zaken was de werking van artikel 134 Overgangswet aan de orde. In dit artikel prijkt de volgende regeling:

'Op een testamentair bewind, ingesteld bij een uiterste wil die is opgemaakt voor het tijdstip van het in werking treden van de wet, is vanaf dat tijdstip of, indien het bewind nadien van kracht wordt, vanaf dit latere tijdstip afdeling 5.7 van Boek 4 van toepassing, behoudens voor zover bepalingen in de uiterste wil daarvan afwijken.'

In de parlementaire stukken (Kamerstukken I/ 1999-2000, 26822, 3, p. 21) leest men het volgende over deze bepaling:

'Het testamentaire bewind is in de geldende wet summier geregeld: zie de artikelen 1066-1069, en voor het bewind over een fideïcommis de artikelen 1025 e.v.; ook aan het vruchtgebruiksbewind wijdt de wet een enkele bepaling in artikel 3:204. Van de vragen die het bewind oproept, is voorts een aantal in de jurisprudentie beantwoord en zijn vele in de literatuur besproken.

$\mathrm{Nu}$ het tegenwoordige recht leemten vertoont en een bij de inwerkingtreding van Boek 4 lopend bewind, anders dan een executele, nog zeer geruime tijd nadien kan voortduren, ligt het voor de hand om voor het overgangsrecht van de nieuwe wetgeving uit te gaan. Wel zij herinnerd aan de artikelen 79 Ow. en 127 van dit wetsvoorstel dat de geldigheid van testamentaire bepalingen die van vóór de inwerkingtreding dateren, ook voor de periode nadien handhaaft, ook voor zover zij van de bepalingen van het nieuwe wetboek afwijken - onverschillig of de nalatenschap die door deze bepalingen wordt geregeld, vóór of na de inwerkingtreding openvalt. Daarnaast bieden de bepalingen van afdeling 4.4.7 op vele punten de bevoegdheid tot testamentaire afwijking van de wettelijke bepalingen; men zie o.a. het in dit verband belangrijke artikel 4.4.7.1q.

\section{Artikel 134}

Het bovenstaande komt erop neer dat van de inwerkingtreding van het nieuwe Boek 4 af op een lopend bewind afdeling 4.4.7 van toepassing is, behoudens voor zover bepalingen in de uiterste wil daarvan afwijken. In zoverre het testament niet zwijgt, ligt het voor de hand dit te respecteren. Hetzelfde geldt voor een bewind dat na de 
inwerkingtreding van het nieuwe erfrecht tot stand komt, indien het voortspruit uit een voordien opgemaakt testament. Aldus artikel 134 van het wetsvoorstel.' (Curs. FS)

Een vergelijkbare regeling treffen we aan in artikel 201 Overgangswet voor het schenkingsbewind. Op zich duidelijke taal in zowel het artikel als in de toelichting. De door mij gecursiveerde zin spreekt boekdelen. Maar blijkbaar kan men toch van mening verschillen wat betreft de strekking van deze overgangsrechtelijke regeling, zo zullen we hierna zien.

Bij beide hoven was per saldo de vraag aan de orde in hoeverre een oud bewind dat levenslang is ingesteld nog aangepakt kan worden met artikel 4:178 lid 2 BW. In deze dwingendrechtelijke regeling is bepaald dat de rechtbank een testamentair beschermingsbewind kan opheffen na verloop van vijf jaren na het overlijden van de erflater op verzoek van de rechthebbende indien aannemelijk is dat de rechthebbende de onder bewind staande goederen zelf op verantwoorde wijze zal kunnen besturen.

Breemhaar is blijkens zijn artikel 'De opheffing van een onder het oude erfrecht ingesteld testamentair bewind', FTV2015/12, van mening dat bij een levenslang bewind artikel 4:178 lid 2 BW toch in stelling kan worden gebracht:

'Ten aanzien van de regeling van het testamentaire bewind in afd. 4.5.7 BW geldt dat de bepalingen ten opzichte van de erflater van dwingend recht zijn, tenzij uit een bepaling zelf blijkt dat de erflater anders kan bepalen (W. Breemhaar, Tijdschrift Erfrecht 2005, nr. 3, p. 44-45). Het slot van art. 134 Ov. NBW heeft blijkens de wetsgeschiedenis het oog op testamentaire clausules die afwijken van hetgeen afd. 4.5.7 BW bij wijze van regelend recht voorschrijft (Kamerstukken II 1999-2000, 26822 , nr. 3, p. 21). [...]

Bij art. 134 slot Ov. NBW past nog de volgende aantekening. Een bewindsclausule die onder het oude recht geoorloofd was, maar die in strijd is met het dwingende recht van afd. 4.5.7 BW, wordt ingevolge art. 79 resp. art. $127 \mathrm{Ov}$. NBW niet alsnog door nietigheid getroffen (Kamerstukken II 1999-2000, 26 822, nr. 3, p. 21). De testamentaire clausule die behelst dat de instelling van het testamentaire bewind voor de duur van het leven van het rechthebbende geschiedt, is echter niet in strijd met een bepaling van dwingend recht van afd. 4.5.7 BW (vgl. 4:177 lid 1 en art. 4:178 lid 1 eerste zin BW). Zij laat evenwel ook de toepasselijkheid van art. 4:178 lid 2 tweede zin BW onverlet, gelijk deze bepaling ook onverkort geldt, indien een testamentair bewind onder het huidige erfrecht uitsluitend in het belang van de rechthebbende voor de duur van diens leven is ingesteld.' (Curs. FS).

Als ik Breemhaar goed begrijp, lijkt hij van mening dat het 'behoudens' van artikel 134 Overgangswet alleen ziet op de nieuwe bewindbepalingen die van regelend recht zijn. En, zoals gezegd, artikel 4:178 lid 2 BW is dwingendrechtelijk van aard.

Ik zie dat anders. Een bepaling waarin is opgenomen dat het bewind slechts eindigt bij overlijden van de rechthebbende geldt mijns inziens als een 'behoudens', zoals bedoeld in artikel 134 Overgangswet, waarmee artikel 4:178 lid 2 BW buiten spel is gezet. Zie preadvies Testamentair bewind naar nieuw erfrecht, Theoretische en praktische varia, Preadvies KNB 2004, p. 47. De beperking die Breemhaar aanbrengt, zie ik noch in de wettekst noch in de toelichting.

In deze zin ook Klaassen-Luijten-Meijer, Erfrecht 2002, p. 292 en later Klaassen-LuijtenMeijer, Erfrecht 2008, p. 315, alsmede B.M.E.M. Schols, Handboek Erfrecht 2015, p. 628. Recent deed Huijgen nog een duit in het zakje met zijn artikel 'Kan een erfrechtbewind uit een testament naar oud erfrecht op grond van artikel 4:178 lid 2 BW worden opgeheven?', JBN 2016/36, naar aanleiding van Rechtbank Amsterdam, 4 februari 2016, ECLI:NL:RBAMS:2016:490, zoals hierna nog te noemen. Ook hij lijkt geen beperking van het 'behoudens' tot bepalingen van regelend recht te zien. 
In de uitspraak van Hof Arnhem-Leeuwarden 7 juli 2016, ECLI:NL:GHARL:2016:5612 krijgt de filosofie van Breemhaar evenwel voet aan de grond, zo blijkt uit de volgende overwegingen:

'3. Voorop gesteld moet worden dat het testamentair bewind is ingesteld over de verkrijging van [Verzoekster] uit de nalatenschap van de erflater onder vigeur van het erfrecht zoals dat tot 1 januari 2003 heeft gegolden, en de nalatenschap van de erflater ook vóór die datum is openvallen. Dit brengt mee dat ingevolge art. 134 Overgangswet nieuw Burgerlijk Wetboek (OnBW) sedert 1 januari 2003 op bedoeld testamentair bewind de bepalingen van afdeling 4.5.7 BW van toepassing zijn, behoudens voor zover, zoals het slot van art. 134 OnBW bepaalt, de bepalingen in de uiterste wil daarvan afwijken. Daarbij moet worden aangetekend dat de bepalingen van afdeling 4.5.7 BW van dwingend recht zijn, tenzij uit een bepaling zelf blijkt dat de erflater anders kan bepalen. Het slot van art. 134 OnBW heeft blijkens de wetsgeschiedenis het oog op testamentaire clausules die afwijken van hetgeen afdeling 4.5.7 BW bij wijze van regelend recht voorschrijft (Kamerstukken II, 1999-2000, 26 822, nr. 3, p. 21). De eerdergenoemde bepaling van art. 4:178 lid 2 tweede zin BW is evenwel van dwingend recht, nu uit die bepaling zelf niet blijkt dat de erflater anders kan bepalen. Overigens kende het oude erfrecht geen met art. 4:178 lid 2 tweede zin BW vergelijkbare bepaling, ook niet een bepaling van die strekking van regelend recht, zodat het hof niet behoeft te onderzoeken of de erflater daarvan bij de instelling van het testamentair bewind is afgeweken.'

Net als Breemhaar komt het hof tot het onderhavige oordeel op basis van de memorie van toelichting. Helaas ontbreekt in de uitspraak een verwijzing naar de literatuur over dit onderwerp. Terzijde wordt opgemerkt dat Breemhaar de beschikking van Hof ArnhemLeeuwarden mede heeft gegeven.

Hof Den Bosch 21 juni 2018, ECLI:NL:GHSHE:2018:2687, doet het anders. Zoals gezegd was ook hier sprake van een levenslang bewind in een 'oud' testament. In eerste aanleg had de rechtbank geoordeeld dat de beëindiging van het bewind op de voet van artikel 4:178 lid 2 BW niet mogelijk was omdat de daarvan afwijkende testamentaire regeling dient te worden geëerbiedigd ondanks het dwingendrechtelijke karakter van artikel 4:178 lid 2 BW. De appellant keerde zich echter tegen dit oordeel en beriep zich daarbij onder meer op de zojuist besproken uitspraak van het Hof Arnhem-Leeuwarden van 7 juli 2016.

Wat is de visie van het Hof Den Bosch? Krijgt artikel 4:178 lid 2 BW grip op het testamentaire bewind of houdt het 'behoudens' in artikel 134 Overgangswet dit tegen? Het Brabantse hof overweegt als volgt:

'4.3.1. Het overgangsrecht neemt als uitgangspunt dat aan het huidig erfrecht onmiddellijke werking toekomt (art. 68a Ow). Op deze hoofdregel bestaan evenwel uitzonderingen. Ingevolge art. $134 \mathrm{Ow}$ is op een testamentair bewind dat is ingesteld bij een vóór 1 januari 2003 opgemaakt testament titel 4.5.7. BW van toepassing, behoudens voor zover bepalingen in het testament daarvan afwijken. Artikel 134 Ow maakt daarbij geen onderscheid tussen bepalingen in het testament die afwijken van een regeling van dwingend of van een regeling van aanvullend recht in titel 4.5.7. BW. Daaruit volgt dat artikel 4:178 lid $2 \mathrm{BW}$, dat van dwingend recht is, niet van toepassing is indien het testament een afwijkende regeling bevat (vgl. Memorie van toelichting (Kamerstukken II 1999/2000, 26822. nr. 3, pagina 21). 4.3.2. De vraag die thans dient te worden beantwoord is of erflaatster in dit verband een van artikel 4:178 lid 2 BW afwijkende regeling heeft getroffen. In het testament is uitdrukkelijk bepaald dat het testamentair bewind eindigt op de dag van overlijden van [appellant] . In beginsel dient er dan ook van uitgegaan te worden dat erflaatster de bedoeling heeft gehad om het testamentair 
bewind te doen gelden voor de duur van het leven van [appellant], zonder de mogelijkheid van tussentijdse beëindiging op verzoek van [appellant], mede in het licht van de verhoudingen die het testament kennelijk wenst te regelen en de omstandigheden waaronder het testament is gemaakt. [...]'

Hof Den Bosch ziet terecht geen overgangsrechtelijk verschil met betrekking tot bepalingen in het oude testament die afwijken van dwingend recht of regelend recht. Breemhaar en Hof Arnhem-Leeuwarden vinden geen navolging in Brabant. Ook Rechtbank Amsterdam 4 februari 2016, ECLI:NL:RBAMS:2016:490, besliste overigens anders dan Hof Arnhem-Leeuwarden.

In mijn bijdrage in het Vakblad Estateplaning, 'Ook aan bewind komt een eind; soms wat later dan verwacht', SDU/Licent 2018/54, behandelde ik bovenstaande materie door de bril van de estate planner. De vraag die daar aan de orde kwam, was of het verstandig kan zijn om in voorkomende gevallen een testament waarin een oud bewind is opgenomen in het geval dat een nieuw testament moet worden opgemaakt niet geheel maar slechts partieel te herroepen, gelet op artikel 134 Overgangswet. Dat is voor de advocaat wellicht wat minder dagelijkse kost. Wat wel dagelijkse kost is, is het inschatten van het procesrisico dat een cliënt loopt indien een overgangsrechtelijk bewindvraagstuk voor de rechter komt. Bij welk forum zal hij met zijn client belanden in het geval er geprocedeerd zou worden? In Arnhem-Leeuwarden dan wel in Den Bosch? In ArnhemLeeuwarden valt het doek voor het bewind immers eerder dan in Den Bosch...

Tot de volgende keer!

Prof. mr. dr. F.W.J.M. Schols

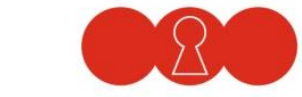

ScholsBurgerhartSchols

www.scholsburgerhartschols.nl

\section{Boomjuridisch}

\author{
Postbus 85576 \\ 2508 CG Den Haag \\ T(070) 3307033 \\ E info@boomjuridisch.nl \\ I www.boomjuridisch.nl
}

